\title{
In Memoriam Prof. Dirk Marie (Dick) Schenkeveld (1934-2021)
}

With sadness the Editorial Board of Mnemosyne received the news of the passing away, on March 15, 2021, of our colleague Dick Schenkeveld at the age of 87 .

Dick Schenkeveld was born in Alkmaar, on January 6, 1934. He studied Classics at the Vrije Universiteit in Amsterdam, where his main teacher was the Platonist Gerrit Jacob de Vries. In 1964 he defended his PhD thesis Studies in Demetrius on Style. He spent a year as a fellow at Harvard's Center for Hellenic Studies in Washington DC (1966) and in 1971 succeeded G.J. de Vries to the Chair of Greek at the Vrije Universiteit, a position from which he retired in 1995. At the Vrije Universiteit he also bore the responsibilities of Dean of the Faculty of Arts (1972-1976), Conrector of the University (Deputy Provost, 1976-1977) and Rector Magnificus of the University (Vice Provost, 1978-1979). For many years (1986-2004) he was the Humanities Secretary of the Royal Holland Society of Sciences in Haarlem, the oldest learned society in the Netherlands.

Dick's research focused on ancient rhetoric, ancient literary criticism and ancient grammar, a field in which he was (and is) widely recognized as a pioneering authority. His final book, A Rhetorical Grammar. C. Iulius Romanus, Introduction to the Liber de adverbio, appeared with Brill in 2004, right before Dick's 7oth birthday.

Dick was a member of our Editorial Board for over twenty years (from 1981 to 2004). Both before and during that period, he contributed a number of important papers to our journal, for instance his series of 'Studies in the History of Ancient Linguistics'; ${ }^{1}$ on Philodemus' take on the kritikoi, who favored 'the ear' as the best criterion for good texts; ${ }^{2}$ or on scholars such as Aristarchus or Strabo and their Homeric interpretations, ${ }^{3}$ to mention but a couple. It is worth mentioning that Dick was a generous and erudite reviewer. Writing a

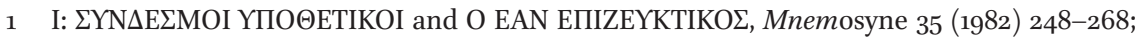
II: Stoic and Peripatetic Kinds of Speech Acts and the Distinction of Grammatical Moods, Mnemosyne 37 (1984) 291-353; III: The Stoic TEXNH ПEPI $\Phi \Omega N H \Sigma$, Mnemosyne 43 (1990) 86-108; IV: Developments in the Study of Ancient Linguistics, Mnemosyne 43 (1990) 289-306.

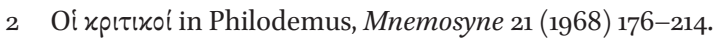

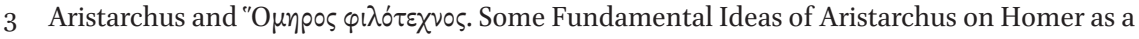
Poet, Mnemosyne 23 (1970) 162-178; Strabo on Homer, Mnemosyne 29 (1976) 52-64. 
good book review is a lot of work, it yields little fame, but it is an enormous service to the profession. Dick excelled at the genre. He wrote dozens of them for Mnemosyne, a steady stream, always based on expert knowledge of the field, with a positively constructive tone, very helpful to the reader.

Dick was a supportive and kind teacher and supervisor. His students included Gerard Boter, André Lardinois, and Ineke Sluiter.

The last decades of Dick's life brought one health disaster after another. He bore all this adversity with cheerful equanimity and great strength. And with unabated love for Classics, above all for Greek with its wonderfully and perpetually alluring alphabet.

The Editorial Board remembers him with gratitude and respect.

\section{Ineke Sluiter}

